\title{
Investigations on transforming Triticum aestivum via the pollen tube pathway
}

\author{
N Martin *, P Forgeois, E Picard \\ INRA-UPS-CNRS, Station de Génétique Végétale, Ferme du Moulon, 91190, Gif-sur-Yvette, France
}

(Received 24 March 1992; accepted 15 May 1992)

\begin{abstract}
Summary - Attempts were made to optimize the necessary conditions to transform wheat Triticum aestivum using the pollen tube pathway. Three methods previously described as successful in cereals and plasmid constructions carrying either NPT II or GUS markers were tested. Functionality of GUS expression vector was checked by particle gun experiments on wheat leaves. Experiments described in this paper show that a Tris- $\mathrm{HCl}-150 \mathrm{mM} \mathrm{pH} 9$ solution containing 0.2 $\mathrm{M} \mathrm{MgSO}_{4}$ inhibits both stigma and pollen nucleases. However, none of the tested plants among the 2731 screened for GUS activity or for their resistance to kanamycin, expressed the reporter genes.
\end{abstract}

Triticum aestivum $=$ wheat $/$ transformation $/$ pollen $/$ nuclease

Résumé - Recherches sur la transformation du blé Triticum aestivum par la voie du tube pollinique. Nous avons tenté d'optimiser les conditions nécessaires pour transformer le blé Triticum aestivum en utilisant la voie du tube pollinique. Trois méthodes ayant été décrites comme des succès chez les céréales et des constructions possédant soit les gènes marqueurs NPTII ou GUS ont été testées. La fonctionnalité de l'expression du gène GUS a été contrôlée au moyen d'un canon à particules sur des feuilles de blé. Les expérimentations décrites montrent que la solution Tris- $\mathrm{HCl} 150 \mathrm{mmol}^{-1} \mathrm{pH}$ contenant 0,2 molot-1 de $\mathrm{MgSO}_{4}$ inhibe les nucléases du pollen et des stigmates. Toutefois aucune des 2731 plantes testées pour leur activité GUS ou leur résistance à la kanamycine n'a exprimé ces gènes marqueurs.

Triticum aestivum $=$ blé $/$ transformation $/$ pollen $/$ nucléase

\section{INTRODUCTION}

Among the cereals, wheat and barley remain the most difficult to transform, mainly because the regeneration step is limiting when in vitro methods are used in transformation experiments. The pollen tube pathway has been considered to be a promising methıd for transformation of the zygote in vivo. Three methods have been mentioned in the literature.

The use of pollen as a DNA vector was first proposed by De Wet et al (1985). In the methods used, pollen grains were incubated in a solution containing exogenous genetic material and then used for pollination. Ohta (1986) and Hess (1987) reported a highly efficient transformation system using a similar method in maize and Nicotiana glauca, but without molecular ev- idence. In these cases 2 explanations for the exogenous DNA uptake by pollen have been suggested: i), the intine of a dry pollen could be leaky for a short time immediately after deposition on the stigmas. During this leaky phase, macromolecules could pass through the intine (Heslop-Harrison, 1979); ii), DNA could be taken up by the tip of the growing pollen tube which lacks cell walls (De Wet et al, 1985). Abdul-Baki et al (1990) demonstrated that the pollen of Nicotiana gossei can incorporate labelled DNA in a pollen germination medium (PGM). Futhermore, electroporation can enhance the percentage of DNA uptake. Aokas (1987) used liposomes to facilitate DNA uptake and demonstrated the incorporation of labelled DNA by pollen. These results confirmed that the pollen tube can be considered as a protoplast near

\footnotetext{
* Correspondence and reprints

Abbreviations : BE: ethidium bromide; BK: Brewbaker and Kwack (1963) elements; NOS: nopaline synthase; 4 MU: 4 methyllumbelliferone; X-Glu: 5-bromo-4 chloro-3 indolyl- glucuronide; MUG: 4 methylumbelliferyl $\beta$ d glucuronide
} 
the tip region and that DNA can be taken up by the pollen tube.

A second method was proposed by Picard et al (1988). After application of a plasmid carrying the NPT II gene on stigmas immediately after pollination, they showed that Triticum aestivum seedlings were resistant to high concentrations of kanamycin and expressed the NPT II gene in their leaves, but transformation could not be proven by molecular evidence.

The third method was described by Zhong and Wu (1988) on rice. After pollination, the stigma was cut off and a DNA solution was applied directly to the style. According to these authors, the DNA solution uses the pollen tube as a microcapillary. Southern experiments revealed the integration of several copies in the genome.

In this paper, we have compared all 3 methods on Triticum aestivum. In addition, preliminary experiments were carried out: $i$ ), to define a pollen germination medium which inhibits the activities of pollen and stigma nucleases; ii), to verify the functionality in wheat of a plasmidial construction by transient expression of the GUS marker via a particle gun.

\section{MATERIALS AND METHODS}

\section{Plant material}

To obtain a wide range of precocity, 5 winter wheat genotypes were chosen: the Moulin variety and 4 lines from a private company, CC Benoîst: 007, 172, 176, 037 . The plants were grown in a greenhouse ( $16 \mathrm{~h}$ daylight, 8000 lux, $24^{\circ} \mathrm{C}$ day, $18{ }^{\circ} \mathrm{C}$ night), from November to January for the study of nuclease activities and in the fields from April to June for the other experiments. After emasculation and pollination, the treated spikes were bagged and all the seeds were collected.

\section{Plasmids}

Two plasmids were used:

- pCIGus (Lee et al, 1991): a pUC9 which contains 35s CaMV promoter, intron Adh1 from maize, a GUS coding region, a NOS $3^{\prime}$ region.

- pLGV 1103-W10-SOD: a pLGV 1103 which contains a NOS promoter, a NPTII coding region, a NOS 3 ' region, a Nos promoter, W10, a polyadenylation terminal sequence and a superoxide dismutase gene (Thomas et al, 1989). W10 is a DNA sequence from wheat which acts like an autonomous replication sequence in yeast (André et al, 1983).
These plasmids were amplified in Escherichia coli, isolated by alkali lysis and purified by CsCl/ethidium bromide density centrifugation (Birnboim and Doly, 1979), and were used together in each plasmid solution.

\section{Particle gun, and test for transient expression}

Embryo culture was performed in vitro over a 2-week period on R9 medium with AIA $10^{-6} \mathrm{M}$ (De Buyser and Henry 1986), to obtain young plantlets. Using a particle gun under the conditions described by Klein et al (1988), plasmids were introducted by 2 successive bombardments into green leaves of plantlets cultivated in vitro. This allowed the functionality of $\mathrm{pClGus}$ in wheat to be controlled by transient expression of Gus activity. Forty-eight hours after the bombardments, the GUS activity was detected by incubating the samples in the histochemical substrate X- GLU solution or by using the fluorometric substrate MUG, according to the Jefferson et al (1987) protocol.

\section{Plasmidial solution}

\section{Composition of the plasmid solutions}

The PSO plasmid solution contained Tris-HCl $150 \mathrm{mM}$ $\mathrm{pH} 9, \mathrm{MgSO}_{4} 200$ mmol. $^{-1}$ with Brewbaker and Kwack elements (1963), and $1 \mu \mathrm{g}$ of plasmid for $20 \mu \mathrm{l}$, osmotic pressure 480 mosmol. To increase DNA absorption by the pollen tube tip liposomes or PEG were added to the plasmid solution PSO. Two plasmid solutions were obtained: PS1 (solution PSO supplemented by $2 \%$ of lipofectine, Gibco BRL) and PS2 (solution PSO supplemented by $5 \%$ PEG 6000; Merck).

\section{Test of the rate of fertilization}

The fertilization rate was obtained by dividing the number of harvested seeds by the number of flowers treated with plasmid solution. This rate was corrected relative to a control without liquid pollination. The fertilization rate was tested for the plasmid solutions possessing the best nuclease inhibitor properties. The plasmid solution with the highest fertilization rate was retained and called PSO.

\section{Nuclease activity test}

To study diffusible nuclease activity during pollination, the Brewbaber and Kwack (1963) mineral medium was buffered with Tris- $\mathrm{HCl} 150 \mathrm{mmol}^{-I^{-1}}$ at various $\mathrm{pH}$ ranging from 5-9 and supplemented with different concentrations of $\mathrm{KNO}_{3}, \mathrm{LiCl}, \mathrm{KH}_{2} \mathrm{PO}_{4}, \mathrm{CaCO}_{2}$, or $\mathrm{MgSl}_{4}$. An osmotic pressure of liquid pollination medium com- 
patible with pollen viability was first determined. The optimal osmotic pressure ranged from 350-750 mos$\mathrm{mol}$ (data not shown). For the buffered Brewbaker and Kwack medium, the osmotic pressure was 250 mosmol. Consequently, to control nuclease activity, concentrations of $\mathrm{KNO}_{3}, \mathrm{LiCl}, \mathrm{KH}_{2} \mathrm{PO}_{4}, \mathrm{CaCl}_{2}$ and $\mathrm{MgSO}_{4}$ were chosen so that the osmotic pressure of the final solution did not exceed 750 mosmol.

For each experiment, 2 spikes of the Moulin variety were pollinated, then 10 ovaries with their stigmas were excised: $0,20,40$ and 60 min after pollination. These ovaries with their stigmas were incubated in $800 \mu \mathrm{l}$ of the plasmid solution containing $40 \mu \mathrm{g}$ of $\mathrm{pCl}$ Gus. At regular time intervals samples were harvested $(20 \mu \mathrm{l})$ and boiled for $7 \mathrm{~min}$ to arrest nuclease activity. These samples were electrophoresed in a $0.8 \%$ agarose gel containing BEt and analysed under UV light. Nuclease activity was observed by the degradation of the plasmid band on the agarose gel. Three intensities of plasmid band were defined to characterize the nuclease protection. The lowest score was given to the absence of the plasmid band, the intermediate notation to the plasmid band that was still visible, the highest notation to the initial stock of DNA that was intact after 20 min of incubation.

\section{Effect of style excision}

To determine the influence of style excision on fertilization rate, the stigmas were excised at different time intervals after pollination: $0,10,20,30,40,50$ and 60 $\mathrm{min}$. Three weeks later, the fertilization rates were compared with pollinated flowers which had kept their styles.

\section{Pollination and application of the DNA solution}

Spikes were emasculated 3 days before normal anthesis (Feeke's stage 10.2). Basal and apical spikelets were removed to increase homogeneity and stigma receptivity. The upper parts of the glumes were cut in order to facilitate manual pollination and application of plasmid solution. Two or 3 days after emasculation, pollen was applied to the stigmas and 10 microliters (containing $2 \mu \mathrm{g}$ of pCiGus and $2 \mu \mathrm{g}$ of pLGV1103W10-SOD) of the solution were applied to the stigmas of each flower.

For transformation via the pollen tube pathway, 3 methods were tested. The first method was adapted from De Wet et al (1985): the plasmid solution was added just after pollination. The second method was the same as that described by Picard et al (1986): the plasmid solution was applied to the pollinated stigmas 20 or 40 min after pollination. The third method was adapted from that of Zhong and Wu (1988): the styles were excised $60 \mathrm{~min}$ after pollination and the plasmid solution was applied immediately to the ovary.

For all 3 methods, the 3 plasmid solutions PSO, PS1, PS2 were tested. The 9 combinations were test- ed for every genotype, except for PS2 on the lines $172,176,037$.

\section{Screening the seeds obtained after transformation assays}

The seedling from the lines 172 and 037 were screened in vitro for their resistance to kanamycin. The caryopses were excised and sterilized for $2 \mathrm{~min}$ in $5 \%(w / w)$ sodium hypochlorite sodium followed by washing with alcohol at $95 \%$. The mature embryos were picked up from imbibed seeds and cultivated for 2 weeks on R9 medium (De Buyser and Henry, 1986) containing $15 \mathrm{mg} / \mathrm{l}$ kanamycin.

The germinated seeds from the Moulin variety and the lines 007 and 176 were screened for Gus activity by fluorometry on the first leaves. The seeds were germinated in plastic Petri dishes and grown in soil during the 3 weeks preceding the test. Leaves (20 $\mathrm{mg})$ were homogenized in $600 \mu \mathrm{l}$ of extraction buffer (50 $\mathrm{mM} \mathrm{Na}_{2} \mathrm{HPO}_{4}, \mathrm{pH} 7,10 \mathrm{mM} \beta$ mercaptoethanol, $10 \mathrm{mM} \mathrm{Na}_{2}$ EDTA, $0.1 \%$ Triton $\times 100$ ). The homogenates were cleared by centrifugation $(10000 \mathrm{~g}), 4 \mathrm{su}$ pernatants $(25 \mu \mathrm{l})$ were mixed with the extraction buffer $(25 \mu \mathrm{l})$ containing $1 \mathrm{mM}$ 4-methyl umbelliferyl glucuronide (MUG) and incubated at $37^{\circ} \mathrm{C}$. The reaction was stopped by adding $300 \mu \mathrm{l}$ of $0.2 \mathrm{M} \mathrm{Na}_{2} \mathrm{CO}_{3}$ at: $30,60,90$ and $120 \mathrm{~min}$. The amount of MU (4methylumbelliferone) was determined fluorometrically (excitation at $365 \mathrm{~nm}$, emission at $455 \mathrm{~nm}$ ). A control signal was established with $50 \mathrm{pM}$ of $\mathrm{MU}$, while background was determined by control leaves. The Gus activity was calculated from the slope of the regression line generated from the time points and normalized to the protein content determined by the Bradford (1976) method.

\section{Statistical analysis}

The analysis of variance on data obtained from pollinations was performed with the module ANVARM of the AMANCE statistical package. It was employed to study the interactions between the 3 plasmid solutions and the different, genotypes of coheat on the fertilization rates. The Moulin variety was studied separately due to its late flowering, and due to the fact that the experiments were performed in warmer conditions.

The binomial law was used as a reference to examine the probability of success and to determine the potentials of the 3 methods used under our conditions. According to the number of tested plants, this law allows us to define a maximal probability for a transformed plant to be obtained, given that no transformed plant was obtained $(\alpha=5 \%)$. $\alpha$ : significance level of the binomial law $(5 \%)$. Risk not to detect or not to obtain a transformed plant when it could be possible. 


\section{RESULTS}

\section{Transient expression}

After bombardment of leaves with the particle gun, histochemical and fluorometric methods were used to detect possible Gus activity. On bombarded leaves, an average of 14.9 blue spots was observed per $\mathrm{cm}^{2}$ with X-GLU as a substrate, and a significantly higher $(119 \%)$ activity was detected with the MUG substrate than with the control (table l).

\section{Pollen and stigma nuclease activities in plasmid solution}

Nuclease activities are $\mathrm{pH}$ dependent. Under the present conditions, in a Tris- $\mathrm{HCl} 150 \mathrm{mM}$ solution, at $\mathrm{pH} 5.5$ complete DNA degradation was observed within the first $30 \mathrm{~s}$ at $20^{\circ} \mathrm{C}$. In the same solution but at $\mathrm{pH} 9.5$, nuclease activity was greatly reduced. To improve the inhibiting properties of the solution different solutions described as nuclease inhibitors were studied (table II). The best results were obtained with the PSO solution (table III; fig 1).

\section{Style excision}

Under the present experimental conditions, excision of the style at different times after pollination was found to reduce the expected fertilization rate when the time period involved was less than $60 \mathrm{~min}$ (fig 2).

Table I. GUS activity by fluorometry after bombardment.

\begin{tabular}{lcc}
\hline & Control & After bomvardement \\
& & \\
\hline Activity & $0.647 \pm 0.143$ & $0.8 \pm 0.183$ \\
No & 0 & $14.9 \pm 14.6$ \\
Not & 12 & 7 \\
\hline
\end{tabular}

Activity expressed in $\mathrm{nM} \mathrm{MU/h/mg/protein} \pm \mathrm{SD}$. No: number of blue spots $/ \mathrm{cm}^{2}$ after 2 successive bombardements on leaves in vitro. Not: number of repetitions of 2 successive bombardments realised on leaves in vitro.
Table II. Nuclease protection.

\begin{tabular}{lcc}
\hline $\mathrm{CaCl}_{2}$ & 180 & 0 \\
$\mathrm{LiCl}$ & 250 & + \\
$\mathrm{KH}_{2} \mathrm{PO}_{4}$ & 330 & + \\
$\mathrm{KNO}_{3}$ & 350 & + \\
$\mathrm{MgSO}_{4}$ & 450 & ++ \\
\hline
\end{tabular}

Inhibiting properties of the solutions containing one salt at a concentration determined for an osmolarity of $500 \mathrm{~m}$ osmol. $O$ : DNA in solution was degraded in the first min after contact with stigma and pollen. +: After $20 \mathrm{~min}$ some DNA was still visible in agarose gel. ++: Initial stock of DNA was still intact after $20 \mathrm{~min}$.

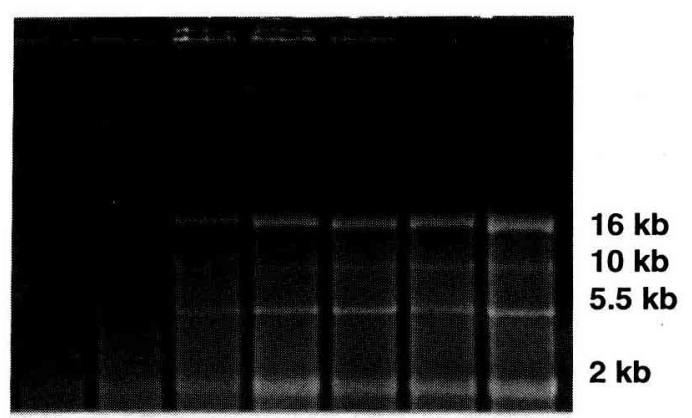

\section{$\begin{array}{lllllll}1 & 2 & 3 & 4 & 5 & 6 & 7\end{array}$}

Fig 1. Nuclease activity in a liquid medium containing Tris$\mathrm{HCl}^{-} 150 \mathrm{mM}, \mathrm{pH} 7.4,0.2 \mathrm{M} \mathrm{MgSO}_{4}$ supplemented with $1 \mu \mathrm{g}$ of plasmid DNA. Lane 1-6: $20 \mu \mathrm{l}$ of the plasmid solution were taken after $20,15,10,5,3,1 \mathrm{~min}$ of incubation. Lane 7 : control treatment.

Table III. Effects of $\mathrm{pH}$ and $\mathrm{MgSO}_{4}$ concentration on nucleases.

\begin{tabular}{|c|c|c|c|}
\hline$p H$ & 7.4 & 8 & 9 \\
\hline$\left[\mathrm{MgSO}_{4}\right]$ & & & \\
\hline $0.1 \mathrm{~mol}-1$ & 0 & 0 & $\begin{array}{l}\stackrel{+}{+} \\
50 \% \text { without BK } \\
88 \% \text { with BK }\end{array}$ \\
\hline $0.2 \mathrm{~mol}^{-1}-1$ & $\begin{array}{l}0 \\
50 \% \text { with BK }\end{array}$ & + & $\begin{array}{c}++ \\
86 \% \text { with BK }\end{array}$ \\
\hline $0.3 \mathrm{~mol}^{\circ} \mathrm{l}^{-1}$ & $\begin{array}{l}++ \\
23 \% \text { with } B K\end{array}$ & ++ & ++ \\
\hline
\end{tabular}

Plasmid solution was buffered by Tris $150 \mathrm{mmol} / \mathrm{l}^{-1}$. Nuclease inhibition: $(0,+,++)$ same as in table $1 . \%$ : Seed set obtained in the greenhouse during winter after applying plasmid solution on stigma which had just pollinated. This rate was corrected relative to a control without applying a plasmid solution. BK: Brewbaker and Kwack (1963) elements. 


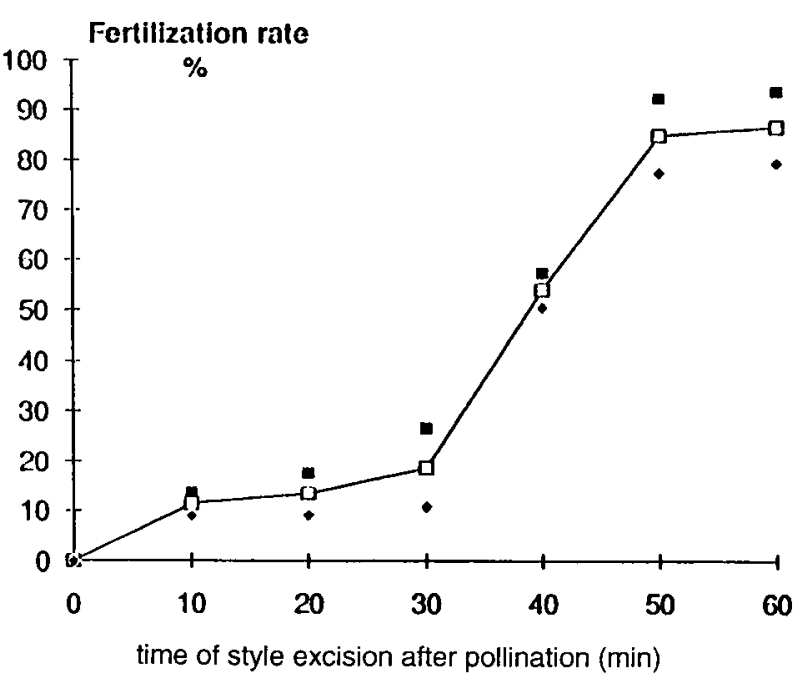

Fig 2. Influence of style excision on fertilization rate. $\mathbf{a}: \%+d$; $\neg \square-;: \%-d$. The fertilization rate obtained after style excision was corrected relative to a control which had retained the styles, the fertilization rate of the control was $100 \%$ ); $d$ : standard deviation.

Table IV. Number of seeds obtained after transformation assays with various solutions and varieties.

\begin{tabular}{|c|c|c|c|c|c|}
\hline Line & 007 & 172 & 176 & 037 & Moulin \\
\hline \multicolumn{6}{|l|}{ PSO } \\
\hline $\mathrm{a}$ & $249 / 628$ & $113 / 610$ & $320 / 660$ & $274 / 654$ & $206 / 704$ \\
\hline$b$ & $24 / 51$ & $20 / 109$ & $107 / 153$ & $23 / 55$ & $37 / 53$ \\
\hline $\mathrm{c}$ & $84.2 \%$ & $100 \%$ & $69.3 \%$ & $100 \%$ & $41.9 \%$ \\
\hline \multicolumn{6}{|l|}{ PS1 } \\
\hline$a$ & $318 / 624$ & $86 / 570$ & $311 / 615$ & $260 / 631$ & $192 / 738$ \\
\hline b & $53 / 99$ & $45 / 96$ & $92 / 139$ & $27 / 49$ & $25 / 34$ \\
\hline c & $95 . \%$ & $32.2 \%$ & $76.4 \%$ & $74.4 \%$ & $35.4 \%$ \\
\hline \multicolumn{6}{|l|}{ PS2 } \\
\hline$a$ & $251 / 584$ & & & & $151 / 648$ \\
\hline $\mathrm{b}$ & $20 / 42$ & & & & $37 / 50$ \\
\hline c & $90.2 \%$ & & & & $31.5 \%$ \\
\hline
\end{tabular}

a: seeds/No of flowers treated with plasmidic solution. b: seeds/No of flowers pollinated (control). $c=a / b$. Plasmid solutions: PSO: Tris-HCl 150 mmolel-1, pH9, $\mathrm{MgSO}_{4} 200$ mmolø $\left.\right|^{-1}$ with Brewbaker and Kwack's elements (1963); PS1: PSO with $2 \%$ of lipofectin; PS2: PSO with 5\% of PEG 600.

\section{Application of the plasmidic sodium}

There was no significant effect and no interaction between plasmid solutions and genotypes on the fertilization rate (table IV). Data on genotypes
Table V. Screening methods for the differents seeds.

\begin{tabular}{lrrrrr}
\hline$T$ & 0 & 20 & 40 & 60 & Total \\
& & & & & \\
\hline Test GUS & 454 & 422 & 627 & 495 & 1998 \\
Test KANA & 174 & 144 & 229 & 186 & 733 \\
Total & 628 & 566 & 856 & 681 & 2731 \\
\hline
\end{tabular}

Test GUS: Number of plants obtained with the fixed lines: Moulin, 007, 176. All these plants were screened by the fluorimetric gus assay. Test KANA: Number of plants obtained with the fixed lines: 037, 172. All these plants were screened for resistance to kanamycin. T: Time (in min) between the application of the DNA solution and pollination.

and plasmid solutions were collected for each application of plasmid solution (table V).

\section{Screening for resistance to kanamycin}

All 733 plantlets from transformation experiments screened for resistance to kanamycin bleached and stopped growing after 2 weeks (table V).

\section{Screening of the seeds by fluorometric assay}

In contrast to the results on transient expression (table I), no positive plant was detected. On the assumption that transformation via the pollen tube pathway is possible and using the binomial law, we can only conclude (at the $5 \%$ level) that the probability to observe a plant expressing the marker under the present experimental conditions was lower than 1\% (table V; annexe 1).

\section{DISCUSSION AND CONCLUSION}

Our aim was to directly transform the egg cell by sexual fertilization. Since 1989, 3 methods using the pollen tube pathway have been proposed. Notwithstanding a certain degree of success, none is in current use.

In this study, 3 methods for wheat transformation via the pollen tube pathway were investigated. Modifications of existing protocols aimed at better protection of exogenous DNA and improvement of DNA uptake by pollen. First of all the particle gun experiments demonstrated that the plasmid construction used (pCIGUS) was 
functional in leaves. For this reason, screening by fluorometric GUS assay, was preferred, but to save time resistance to kanamycin was used in lines 172 and 037.

To establish an efficient pollination medium protecting DNA from the DNase activities, the BK medium was used which is known to improve pollen germination. It was buffered with $150 \mathrm{mM}$ Tris- $\mathrm{HCl}$ to prevent pollen from bursting, as described by Vergne and Dumas (1988). Then, by adding different concentrations of saline solutions, inhibition of both pollen and stigma nucleases was attempted. $\mathrm{LiCl}$ and $\mathrm{CaCl}_{2}$ as used in yeast and bacterial transformation were tested in order to use their effect on permeability with the pollen tube tip. $\mathrm{KH}_{2} \mathrm{PO}_{4}$ was also tested since phosphate has been described as a petunia pollen nuclease inhibitor (Van Der Westhuizen et al, 1987). Finally, 2 elements were tested from the Brewbaker and Kwack medium: $\mathrm{KNO}_{3}$ and $\mathrm{MgSO}_{4}$, described as efficient nuclease inhibitors in maize (Roeckel et al, 1988). In the range of concentrations tested, $\mathrm{MgSO}_{4}$ provides the best inhibiting, properties. We have shown that the inhibiting properties of the solution increased under basic conditions, as described by Matousek and Tupy (1985). The PSO solution which protects against nuclease activity was supplemented by permeabilizing agents to increase DNA uptake into pollen. Since Gad et al (1988) have shown the fusion of liposomes with a tube tip we used lipofectin, which shows high efficiency in mammalian cell transformation (Felgner et al, 1987). PEG 5\% was also used, since this molecule increases protoplast transformation (Negrutiu et al, 1987). The use of these particular plasmid solutions under the present conditions allowed a similar fertilization rate to be obtained for all the lines, reaching $69 \%$ of that in the control.

Concerning the transformation methods, the strategy was based upon the plasmid capacity to reach the ovule by using the pollen tube pathway. Lange et al (1976) and Jalani and Moss (1988) observed that pollen grains of Triticum aestivum germinated within the first $5 \mathrm{~min}$ after pollination. Fifteen to 20 min later, pollen tubes reached the base of the style, and the time needed by the fastest tubes to reach the embryo sac was $30-40 \mathrm{~min}$ at about $20^{\circ} \mathrm{C}$.

According to these data, the plasmid solution was applied 4 times to the pollinated stigmas. First, to exploit the leaky phase described by Heslop-Harrison (1979) or the possible DNA uptake by the pollen tube tip, the plasmid solution was applied to the stigma just after pollination $\left(T=O^{\prime}\right)$. Second, to exploit the possibility of DNA flowing down the pollen tube, 3 application times were determined: 20,40 or 60 min after pollination. The protocol of Picard et al (1988) was used at the application times of 20 and $40 \mathrm{~min}$. As observed (fig 3), style excision had no effect on fertilization rate after $60 \mathrm{~min}$, styles were excised only for the last application time (60 min), and the protocol of Zhong et al (1988) was adapted to wheat at the application time of $60 \mathrm{~min}$.

Concerning the transformation markers, it was concluded that there was no GUS expression in tested plants, and among the plants screened for kanamycin resistance, none was resistant. In spite of the fact that it is not known whether the NPT $\|$ gene is functional or not in Triticum aestivum, the antibiotic concentration was lower than that usually used for the screening of transformed Triticum monococcum protoplasts: 75 mg..$^{-1}$ (Lörz et al, 1985). However, in all cases, the plants were screened only for the expression of reporter genes. According to Gordon-Kamm et al (1990), transgenic maize plants have been obtained but in some cases the integration does not result in the expression of the foreign gene. Taking into account the number of treated plants, the efficiency of transformation, if any, can be evaluated.

For the first method, the efficiency appears to be less than $1 \%$. It has already been proven that DNA can enter pollen (Abdul-Baki et al, 1990). Nevertheless, it has been shown that fluorescence-labelled molecules cannot enter a sperm cell (Heslop-Harrison et al, 1988) because there are 2 barriers constituted by the plasma membrane of generative and sperm cells. It would be difficult for the plasmid to reach the egg cell. In view of this, the particle gun could be a good tool to transfer DNA to a sperm nucleus (Twell et al, 1989).

Using the second method, Mendel et al (1990) obtained whole transformed barley plants, and claimed a transformation rate of $10^{-4}$ to $10^{-3}$. From the present statistical analysis, it can only be concluded that under the present experimental conditions the transformation rate was lower than $10^{-2}$ in wheat.

Using the third method tested, Zhong and Wu (1988) obtained a $20 \%$ transformation rate in rice. After testing 681 wheat plants (table V), we concluded that the transformation rate if any, was lower than $1 \%$, and thus that this method is probably not applicable to wheat. 
Finally, under the present conditions, the probability of success is lower than $1 \%$ and the methods are tedious, without guarantee of success. Recently, Inagaki et al (1988), Redway et al (1990) and Jähne et al (1991) reported wheat and barley regenerations from cellular suspensions, while Vilma et al (1991) obtained stable transformed callus lines from microprojectile bombardment of cell suspension cultures of wheat. Using the particle gun on a cell suspension capable of regeneration could be the best method to obtain whole transformed wheat plants.

\section{ANNEXE 1}

An attempt is made to transform $n$ plants. Let us assume that the trials are independent of one another and have the same probability $p$ of success. The number of successes is distributed in a binomial manner $(n, p)$. No success has been observed. The probability of such an event is:

$$
p(x=0)=(1-p)^{n}
$$

We look for a confidence interval for $p$.

$(1-p)^{n}$ is a decreasing function of $p$, equal to 1 for $p=0$.

( $p$ is certainly small, or the probability of the result would be very small)

A confidence interval, at the level $1-\alpha$ is given by the value $p_{\alpha}$, the solution of :

$$
\left(1-p_{\alpha}\right)^{n}=\alpha \text { or } p_{\alpha}=1-\alpha^{n}
$$

For $n=2731$, this gives:

$$
\begin{array}{lllll}
\alpha & 0.50 & 0.10 & 0.05 & 0.01
\end{array}
$$

$p_{\alpha} 2.5 \times 10^{-4} 8.4 \times 10^{-4} 1.1 \times 10^{-3} 1.7 \times 10^{-3}$

The lower limit, which is part of the interval, is 0 . Thus at $\alpha=0.05$, the probability of transformation is comprised between 0 and $1.1 \times 10^{-3}$, boundaries included.

\section{ACKNOWLEDGMENTS}

We thank PY Collin, E Crambes, C Martin, E Mihamound, $S$ Rigo and $\mathrm{CC}$ Benoîst Company for technical assistance; $M$ Kreis and $M$ Thomas for kindly providing pCIGUS; Roussel-Uclaf/Calgene for providing the MnSOD gene; JM Jacquemin and D Mingeot for the gift of PLGV-1103-W10-SOD; C Damerval, J De Buy- ser, $Y$ Henry and $D$ de Vienne who helped us to improve the manuscript, and LL Huffman for correcting the English. We also thank Roussel-Uclaf for supporting this research.

\section{REFERENCES}

Abdul-Baki AA, Sauders JA, Matthews BF, Pittarelli GW (1990) DNA uptake during electroporation of germinating pollen grains. Plant Sci 70, 181-190

André D, Jacquemin JM, Masson P (1983) Isolation and characterisation of DNA sequences from Triticum aestivum which function as origin of replication in Saccharomyces cerevisiae. Plant Cell Rep 2, 175-178

Aokas H (1987) Transfection by DNA-associated liposomes evidenced at pea pollination. Hereditas 106, 129-138

Birnboïm HC, Doly J (1979) A rapid alkaline extraction procedure for screening recombinant plasmid DNA. Nucleic Acids Res 7, 1513

Bradford MM (1976) A rapid and sensitive method for the quantitation of microgram quantities of protein utilising the principle of protein dye binding. Anal Biochem 72, 248-254

Brewbaker JL, Kwack BH (1963) The essential role of calcium ion in pollen germination and pollen tube growth. Am J Bot 50, 859-865

De Buyser J, Henry Y (1986) Production of haploids, performance of doubled haploids and yield trials. In: Biotechnology in Agriculture and Forestry 2. Crops I(YPS Bajaj, ed) 73-85

De Wet JMJ, Bergquist RR, Harlan JR, Brink DE, Cohen CE, Newell CA, De Wet AE (1985) Exogenous Gene Transfer in Maize (Zea mays) Using DNATreated Pollen. Experimental Manipulation of Ovule Tissue. Longman, London, 197-209

Felgner PL, Gadek TR, Holm M, Roman R, Chan HW, Wenz M, Northrop JP, Ringold GM, Danielsen M (1987) Lipofection, a highly efficient liquidmediated DNA-transfection procedure. Proc Natl Acad Sci USA 84, 741-7417

Gad AE, Zeewi BZ, Altman A (1988) Fusion of germinating watermelon pollen tubes with liposomes. Plant Sci 55, 69-75

Gordon-Kamm WJ, Spencer TM, Mangano ML, Adams TR, Daines RJ, Start WG, O'Brien JV, Chambers SA, Adams WR, Willets NG, Rice TB, Mackey CJ, Krueger RW, Kausch AP, Lemaux GL (1990) Transformation of maize cells and regeneration of fertile transgenic plants. Plant Cell 2, 603-618

Heslop-Harrison J (1979) Aspects of the structure, cytochemistry and germination of the pollen of rye (Secale cereale L). Ann Bot (Lond) 144, 1-47

Heslop-Harrison J, Heslop-Harrison Y (1988) Some permeability properties of angiosperm pollen grains, pollen tubes and generative cells. Sexual Plant Reprod 1, 65-73 
Hess D (1987) Pollen based techniques in genetic manipulations. Int Rev Cytol 107, 169-190

Inagaki M, De Buyser J, Henry Y (1988) Occurrence of somatic embryoids in suspension callus cultures initiated from immature haploid wheat embryos. Jpn J Breed 38, 103-107

Jähne A, Lazzeri PA, Jager-Gussen M, Lorz H (1991) Plant regeneration from embryogenic cell suspension derived from another cultures of barley (Hordeum vulgare L). Theor App/ Genet 82, 74-80

Jalani BS, Moss JP (1980) The site of action of the crossability genes $\left(\mathrm{Kr}_{1}, \mathrm{Kr}_{2}\right)$ between Triticum and Secale. I. Pollen germination, pollen tube growth, and number of pollen tubes. Euphytica 29, 571-579

Jefferson RA, Kavanagh TA, Bevan MW (1987) GUS fusions: bd-glucuronidase as a sensitive and versatile gene fusion marker in higher plants. EMBO J6, 3901-3907

Klein TM, Gradziel T, Fromm ME, Sanford JC (1988) Factors influencing gene delivery into Zea mays cells by high-velocity microprojectiles. Biotechnology 6, 559-563

Lange W, Wojciechowska B (1976) The crossing of common wheat (Triticum aestivum $L$ ) with cultivated rye (Secale cereale L). I. Crossability, pollen grain germination and pollen tube growth. Euphytica 25, 609-620

Lee B, Murdoch K, Topping J, Jones MGK, Kreis M (1991) Transient expression of foreign genes introduced into barley endosperm protoplasts by PEGmediated transfer or into intact endosperm tissue by microprojectile bombardment. Plant Sci 78, 237246

Lörz H, Baker B, Schell J (1985) Gene tranfer to cereal cells mediated by protoplast transformation. Mol Gen Genet 199, 178-182

Matousek J, Tupy J (1985) The release and some properties of nuclease from various pollen species. J Plant Physiol 119, 169-178

Mendel RR, Clauss E, Hellmund R, Schulze J, Stenbib HH, Tewes A (1990) Gene transfer to barley. In: Proc VIIth Int Congr Plant Tissue and Cell Culture.
Progress in Plant Cellular and Molecular Biology. Amsterdam, 73-78

Negrutiu I, Shillito R, Potrykus 1, Biasini G, Sala F (1987) Hybrid genes in the analysis of transformation condiitons. Plant Mol Biol 8, 363-373

Ohta $Y$ (1986) High efficiency genetic transformation of maize by a mixture of pollen and exogenous DNA. Proc Natl Acad Sci USA 83, 715-719

Picard E, Jacquemin JM, Granier F, Bobin M, Forgeois $P$ (1988) Genetic tranformation of wheat (Triticum aestivum) by plasmid DNA uptake during pollen tube germination. In: VIIth Int Wheat Genetics Symp. Cambridge, 779-781

Redway FA, Vasil V, Vasil IK (1990) Characterisation and regeneration of wheat (Triticum aestivum $\mathrm{L}$ ) embryogenic cell suspension cultures. Plant Cell Rep 8, 714-717

Roeckel P, Heizmann P, Dubois M, Dumas C (1988) Attempts to transform Zea mays via pollen grains. Sexual Plant Reprod 1, 156-163

Thomas B, Davies HM, Kridl J, Van Asshe CJ O'Neal J (1989) Patent: WO 90/01260

Twell D, Klein TM Fromm ME, McCormick S (1989) Transient expression of chimeric genes delivered into pollen by micro projectile bombardment. Plant Physiol 91, 1270-1274

Van Der Westhuizen AJ, Gliemeroth AK, Wenzel W, Hess D (1987) Isolation and partial characterization of an extracellular nuclease from pollen of Petunia hybrida. J Plant Physiol 131, 373-384

Vergne $P$, Dumas $C$ (1988) Isolation of viable wheat male gametophytes of different stages of development and variations in their protein patterns. Plant Physiol 88, 969-972

Vilma V, Brown SM, Re D, Fromm ME, Vasil IK (1991) Stably transformed callus lines from microprojectile bombarment of cell suspension cultures of wheat. Bio technology 9, 743-747

Zhong-Xun L, Wu R (1988) A simple method for the transformation of rice via the pollen tube pathway. Plant Mol Biol Rep 6, 165-174 